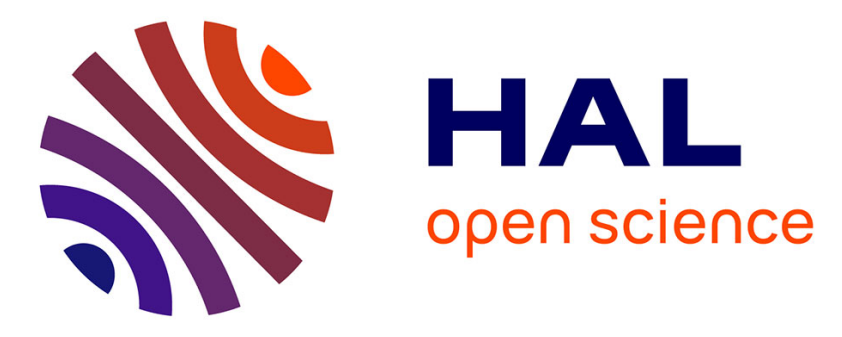

\title{
Synthesis of new star-like triply ferrocenylated compounds
}

\author{
Juan Santos, F. Madrid-Moliné, C.A. Cisternas, Frédéric Paul, C.A. Escobar, \\ P. Jara-Ulloa, A. Trujillo
}

\section{- To cite this version:}

Juan Santos, F. Madrid-Moliné, C.A. Cisternas, Frédéric Paul, C.A. Escobar, et al.. Synthesis of new star-like triply ferrocenylated compounds. Inorganica Chimica Acta, 2019, 486 (3), pp.95-100. 10.1016/j.ica.2018.10.038 . hal-01939033

\section{HAL Id: hal-01939033 https://hal-univ-rennes1.archives-ouvertes.fr/hal-01939033}

Submitted on 13 Dec 2018

HAL is a multi-disciplinary open access archive for the deposit and dissemination of scientific research documents, whether they are published or not. The documents may come from teaching and research institutions in France or abroad, or from public or private research centers.
L'archive ouverte pluridisciplinaire HAL, est destinée au dépôt et à la diffusion de documents scientifiques de niveau recherche, publiés ou non, émanant des établissements d'enseignement et de recherche français ou étrangers, des laboratoires publics ou privés. 


\title{
Synthesis of new star-like triply ferrocenylated compounds.
}

\author{
Juan C. Santos ${ }^{\mathrm{a}}$, Franco Madrid-Molinéa ${ }^{\text {, Carlos A. Cisternas }}{ }^{\mathrm{a}}$, Frédéric Paul ${ }^{\mathrm{b}}$, Carlos A. \\ Escobar ${ }^{\mathrm{a}}$, Paola Jara-Ulloa ${ }^{\mathrm{a}}$, Alexander Trujillo*a \\ ${ }^{a}$ Universidad Andres Bello, Facultad de Ciencias Exactas. Departamento de Ciencias Químicas. Av.
} Republica 275, Santiago, Chile. E-mail : alexander.trujillo@unab.cl

${ }^{b}$ Institut des Sciences Chimiques de Rennes UMR 6226 CNRS. Université de Rennes 1. Campus de Beaulieu. Bat. 10C. 35042 Rennes Cedex, France.

Keywords: Redox-active ferrocenyl-based compounds $・$ Time-dependent DFT $・ \mathrm{Uv}-\mathrm{Vis}$ Absorption $\bullet$ Cyclic Voltammetry

Abstract: New ferrocenyl-subtituted compounds containing two different central cores (isocyanurate and 1,3,5-phenylene) and extended by two kinds of branches bearing both vinyl ferrocenyl (1 and 3) and cross-conjugated ferrocenyl-chalcone (2, 4 and $\mathbf{5})$ as endgroups have been synthetized and characterized both spectroscopically and electrochemically. These molecules have been synthesized in order to investigate the electronic properties imparted by both types of branches when they are connected to the central core. For all compounds, electrochemical studies have showed a simultaneous oxidation of all ferrocene units present in each compound. For all of them, except for compound 2, a chemically reversible oxidation wave on the voltammograms has been observed. In contrast, for compound 2, a chemically irreversible oxidation wave is obtained. Moreover, the vinyl ferrocenyl derivatives have presented a lower redox peak potential with respect to ferrocene standard compound, and the ferrocenyl-chalcone bearing derivatives, in accordance with a change in the electron releasing capability of these endgroups, have been oxidized at a higher potential.

Bathochromic shifts of the active transitions in Uv-Vis region have been observed, which are associated to the presence of carbonyl groups in those molecular structures containing

it. These results are in agreement with theoretically calculated transition energies, which have been obtained for compounds $\mathbf{1}$ and $\mathbf{2}$ using Time Dependent Density Functional Theory (TD-DFT).

\section{Introduction}

The electron-donating characteristics of the ferrocenyl group, the electron-withdrawing properties of the oxidized ferrocenium species, the high thermal stability of both the 
oxidized and the reduced states, and the electrochemical reversible nature of the $\mathrm{Fc} / \mathrm{Fc}^{+}$ couple are the main reasons for using ferrocene $(\mathrm{Fc})$ derivatives as molecular sensors and/or energy transfer processes[1-6].

In view of this, in the last years an increasing interest has been devoted to the design and synthesis of complex systems capable of generating an electrochemical response, among them ferrocene moieties, in which the structural and electronic properties may be influenced by appropriate chemical or physical stimulus, has been the focus of many studies[7-10].

In this context, following the search for new ferrocene containing materials[11], we are describing here the synthesis and characterization of five new star-like compounds bearing ferrocenyl endgroups featuring isocyanurate and 1,3,5-phenylene cores. The main objective of this work is to evaluate the electron conjugation effect across the central cores bearing two kinds of branches: the vinyl ferrocenyl and the cross-conjugated ferrocenyl-chalcone, on the electrochemical potentials of the $\mathrm{Fc} / \mathrm{Fc}^{+}$couple and on the changes produced on lowest energy transition of electronic absorption spectra.

\section{Results and Discussion}

\subsection{Synthesis and Characterization}

Two different $\mathrm{C}-\mathrm{C}$ coupling reactions were used to obtain the described compounds (Scheme 1). Compounds $\mathbf{1}$ and $\mathbf{3}$ were synthesized using the Heck coupling reaction between the vinyl ferrocene, 1-Fc[12], and one of the following center cores: C1[13] and C2[14]. Whereas for the compounds 2, 4 and 5, Sonogashira cross coupling reaction was used not only to link together the new ferrocenyl-chalcone, 2-Fc[15] with $\mathbf{C 1}$ center core but also, the bromide chalcones 3-Fc and 4-Fc[16] with $\mathbf{C 3}[14]$ center core. All compounds were isolated as a dark-red powder with yields ranging from 40.6-56.5\% and were spectroscopically characterized. In all of these compounds a ferrocenyl fragment was connected to a center core through a chalcone and/or a vinyl group as a linker moiety with the aim to study their electronic properties when they are connected to conjugated (i.e. vinyl) or cross-conjugated (i.e. chalcone) bridges and to understand their influence on the linear optical properties (Uv-Vis). 

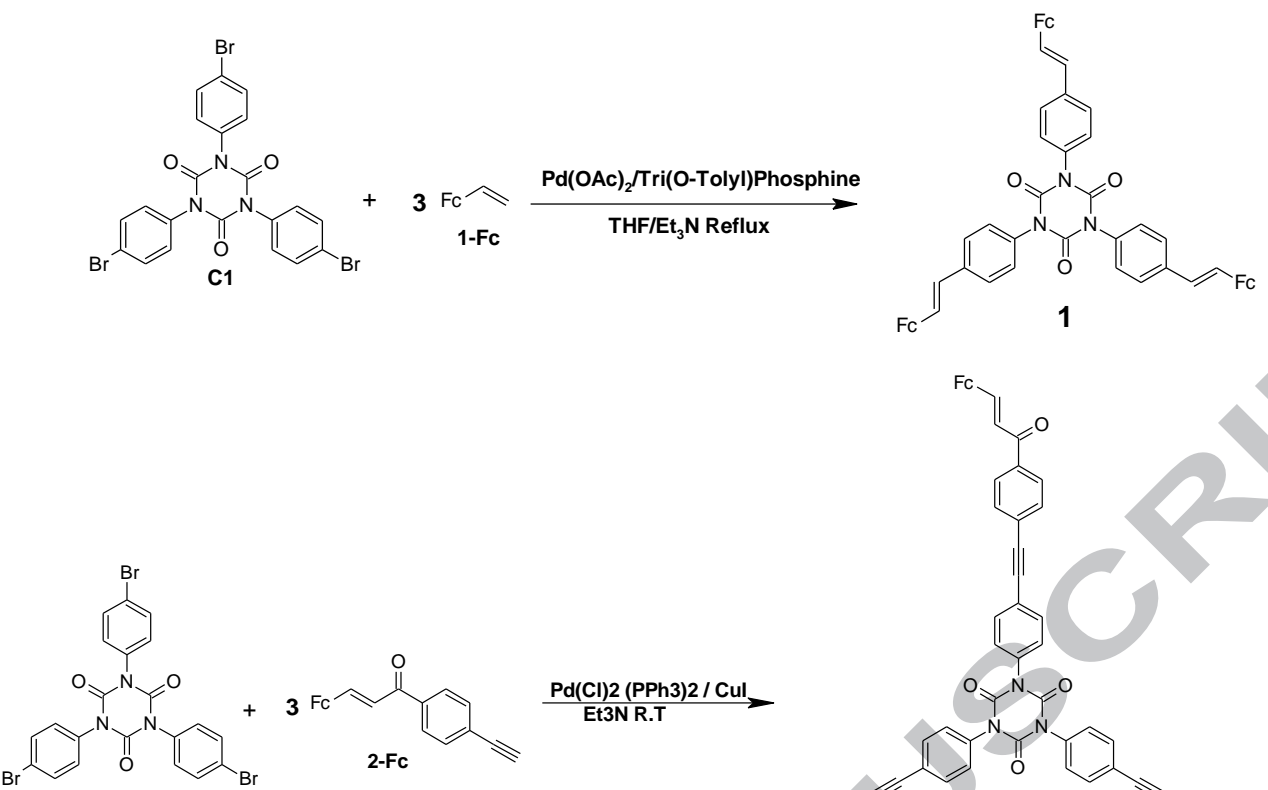

Et3N R.T

C1
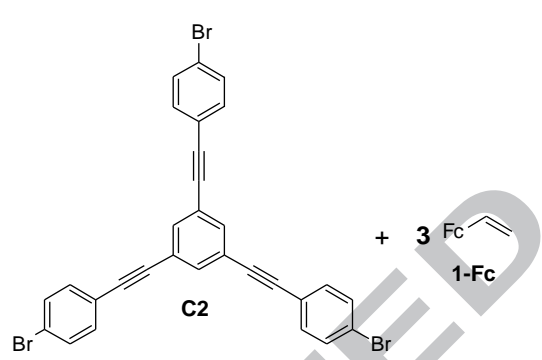

Ac) $)_{2}$ Tri(O-Tolyl)Phosphine
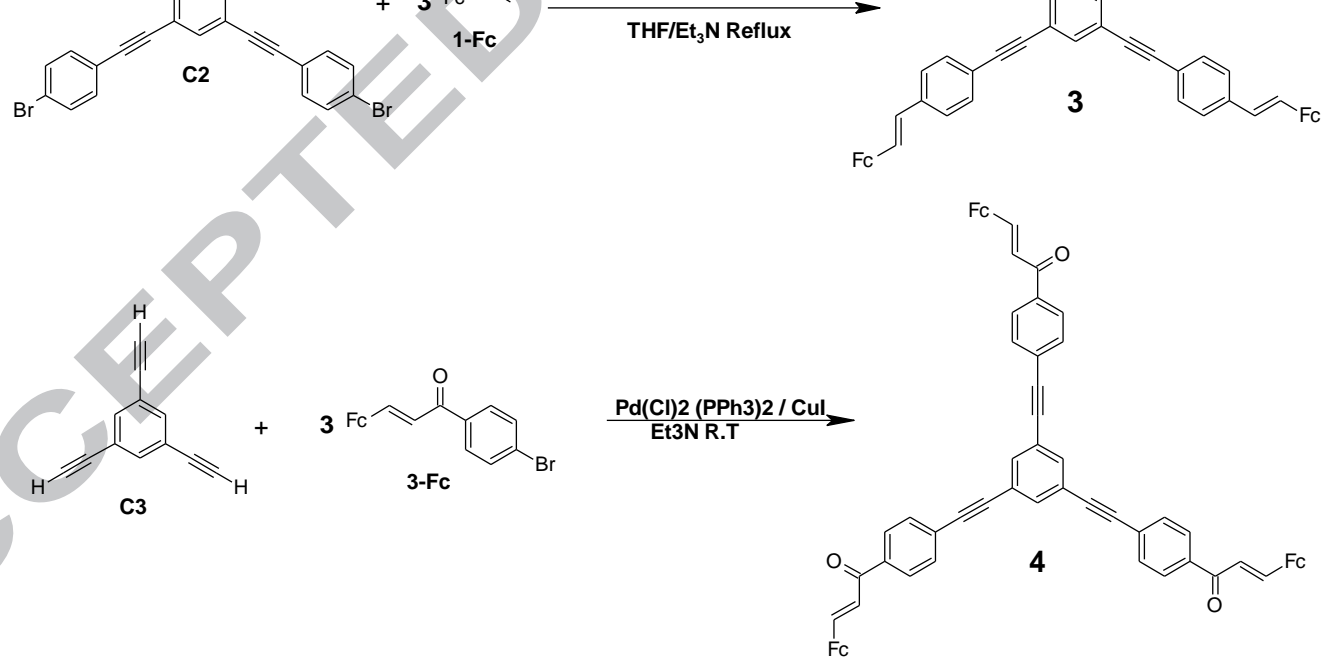


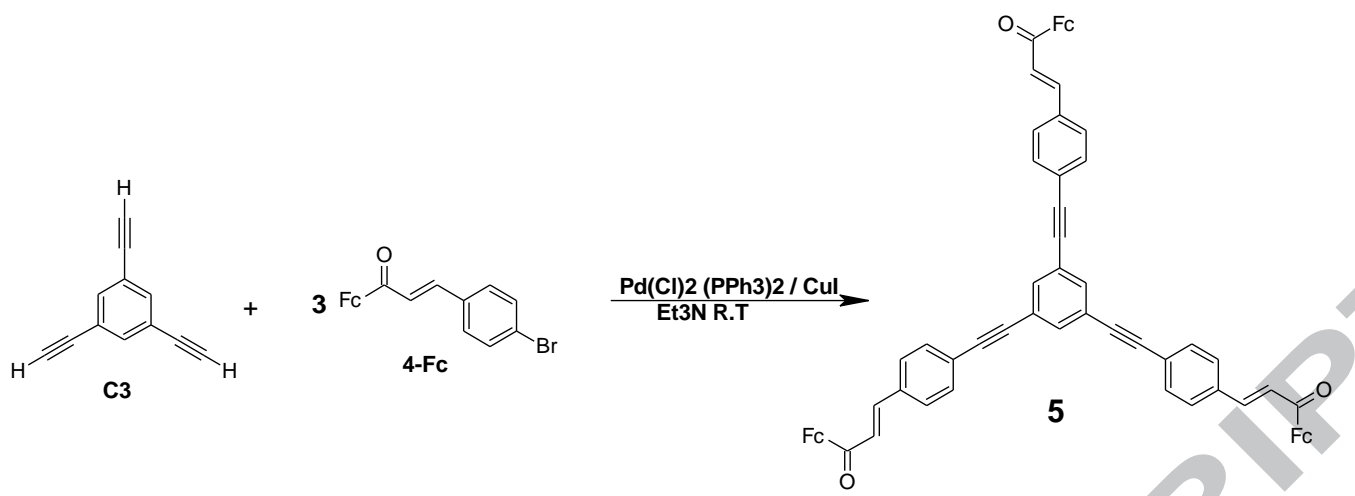

Scheme 1. Synthesis of compounds 1-5.

All the new compounds were characterized by $\mathrm{IR},{ }^{1} \mathrm{H},{ }^{13} \mathrm{C} \mathrm{NMR}$ and Uv-visible spectroscopy. For compounds $\mathbf{1}$ and $\mathbf{3}$, the presence of the vinyl group was evidenced by an absorption at $1590 \mathrm{~cm}^{-1}$ and $1578 \mathrm{~cm}^{-1}$, respectively, in infrared spectroscopy, corresponding to the $-\mathrm{C}=\mathrm{C}$ - stretching mode. Whereas for the compounds 2, 4 and $\mathbf{5}$ the conjugated double bond was observed at 1588, 1589 and $1597 \mathrm{~cm}^{-1}$, respectively. Ferrocene-chalcone backbone, showed a characteristic $\mathrm{C}=\mathrm{O}$ stretching peak at $1655 \mathrm{~cm}^{-1}$, for 2 and 4 , and $1652 \mathrm{~cm}^{-1}$ for 5 , typical for conjugated carbonyls. Additionally, for compounds 1 and $\mathbf{2}$ a very strong absorption was also observed at 1713 and $1719 \mathrm{~cm}^{-1}$, which can be attributed to one of the $\mathrm{C}=\mathrm{O}$ vibrating modes of the carbonyl group of the isocyanurate core (Table 1).

In the ${ }^{1} \mathrm{H}-\mathrm{NMR}$ spectrum, three distinctive principal regions of signals could be identified for all compounds. The first one is the typical pattern of signals expected for the ferrocenyl fragment, with a singlet at $c a .4 .17 \mathrm{ppm}$, corresponding to the unsubstituted cyclopentadienyl ring and two broad singlets at ca. $4.44 \mathrm{ppm}$ and ca. $4.60 \mathrm{ppm}$, corresponding to the substituted cyclopentadienyl ring. A slight variation in the chemical shifts on the ferrocenyl protons was observed in those compounds containing the carbonyl moiety in their structure (i.e. compounds $\mathbf{2 , 4}$ and 5), shifting the proton NMR signal to a lower field compared with those found in compounds $\mathbf{1}$ and $\mathbf{3}$. Another set of signals corresponds to the vinylic protons. The coupling constants for these protons in all compounds are between ${ }^{3} J=15.0$ and $16.0 \mathrm{~Hz}$, suggesting both a trans geometry of the double bond and a s-cis conformation with the carbonyl double bond, for $\mathbf{2 , 4}$ and $\mathbf{5}$. The last sets of signals correspond to the aromatic protons with signals in the range of 7.59-7.97 ppm. 


\subsection{Uv-Vis Spectroscopy}

The Uv-Vis spectra of all new compounds 1-5 were recorded in dichloromethane. These absorption spectra display two or four characteristic peaks (Table 1 and Supplementary Material, figures SI-7 to SI-9). The absorption coefficients vary from 7400 to $54700 \mathrm{M}^{-}$ ${ }^{1} \cdot \mathrm{cm}^{-1}$. The origin of the high-energy absorption band, in the range of 269-347 nm, is assumed to be an intraligand $\pi-\pi$ charge-transfer (ILCT) transition. And the low-energy absorption band in the region of 463-511 $\mathrm{nm}$ is assumed to be a d-d transition of the iron in the ferrocene moiety and $d \rightarrow \pi^{*}$ metal-to-ligand charge transfer (MLCT) transition from the $\mathrm{Fe}(\mathrm{d})$ orbital to the organic moiety orbital $\left(\pi^{*}\right)[17,18]$.

A bathochromic shift of this transition is observed in the compound $\mathbf{2}$, with respect to compound 1, possibly attributed to the presence of the two acceptor groups, central core and carbonyl group of the chalcone fragment in the structure 2. Likewise, the MLCT takes place at even lower energy in the $\mathbf{4}$ and $\mathbf{5}$ when compared with $\mathbf{3}$, which does not have a carbonyl group in its structure. Regarding the intense ILCT transition at higher energy in 15, the latter experiences also a bathochromic shift depending on the size of the $\pi$ conjugated manifold of the central core. As expected based on such considerations, this intense ILCT transition is found at lowest energy for compound 2 (Figure 1). Timedependent density functional theory (TD-DFT) calculations were used to obtain the theoretical absorption spectra and Kohn-Sham orbitals (Supplementary Material, pages SI10 to SI-12). Among the result it can be mentioned that the bathochromic shift of the active transitions in Uy-Vis region was observed in the compounds $\mathbf{1}$ and 2. The HOMO (H)LUMO (L) gap in $1(3.86 \mathrm{eV})$ is higher than $2(3.14 \mathrm{eV})$ yielding transitions with lowest energies in the latter compound. Also, according to the TD-DFT calculations for compound 1, the transitions located around $630 \mathrm{~nm}$, are predicted mainly as transitions between the

$\mathrm{d} \pi$-type orbitals $\left(\mathrm{H}-3, \mathrm{H}-4\right.$ and H-5) of three Fe atoms to $\pi^{*}$-type orbitals $(\mathrm{L}+13, \mathrm{~L}+12$, $\mathrm{L}+11)$ of the three cyclopentadienyl moieties.

When transitions around $508 \mathrm{~nm}$ were calculated, they showed that mainly involve the same transitions described before in addition with the transitions between the d $\pi$-type orbitals (H-9, H-10 and H-11) centered over three Fe atoms to $\pi^{*}$-type orbitals $(\mathrm{L}+14$, $\mathrm{L}+15, \mathrm{~L}+16)$ of the delocalized bridge were found. The transition with the highest oscillator strength, accounts for the band around $320 \mathrm{~nm}$ and constitute the $\pi-\pi^{*}$ excitation from 
ligand bridges. These transitions are mainly composed for contributions of $\mathrm{H}-6 \rightarrow \mathrm{L}, \mathrm{H}-$ $7 \rightarrow \mathrm{L}+2$ and $\mathrm{H}-8 \rightarrow \mathrm{L}+1$ excitations.

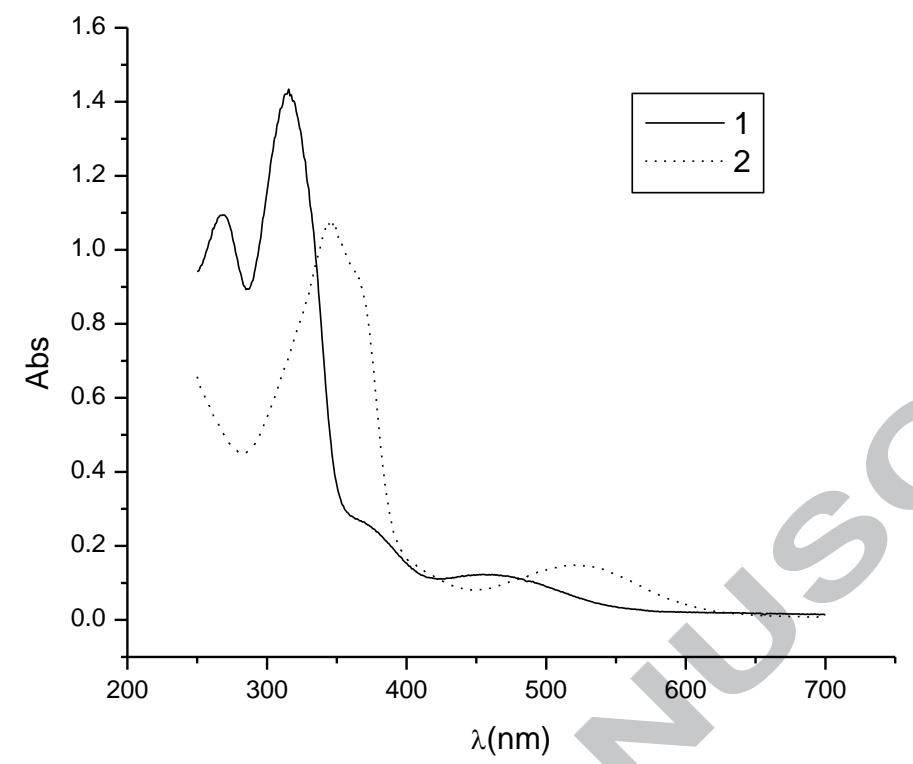

Figure 1. Uv-Vis spectra of compounds $\mathbf{1}$ and $\mathbf{2}$ in $\mathrm{CH}_{2} \mathrm{Cl}_{2}$.

Table 1. Characterization data of compound 1-5: principal IR stretching absorptions and maximum wavelength of absorption.

\begin{tabular}{|c|c|c|c|c|}
\hline \multirow{2}{*}{ Compound } & \multicolumn{2}{|c|}{ Wavenumber $\left(\mathrm{cm}^{-1}\right)$} & \multirow[b]{2}{*}{$\mathbf{C}=\mathbf{O}^{* *}$} & \multirow{2}{*}{$\lambda_{\max }(\mathrm{nm})$} \\
\hline & $\mathrm{C}=\mathrm{C}$ & $C=0^{*}$ & & \\
\hline \multirow{5}{*}{1} & \multirow{5}{*}{1590} & \multirow{5}{*}{1713} & \multirow{4}{*}{--- } & 269 \\
\hline & & & & 316 \\
\hline & & & & 379 (sh) \\
\hline & & & & 463 \\
\hline & & & & 347 \\
\hline \multirow[t]{2}{*}{2} & \multirow[t]{2}{*}{1588} & \multirow[t]{2}{*}{1719} & \multirow[t]{2}{*}{1655} & 366 \\
\hline & & & & 523 \\
\hline \multirow{2}{*}{3} & \multirow{2}{*}{1578} & \multirow{2}{*}{--- } & \multirow{2}{*}{--- } & 343 \\
\hline & & & & 477 \\
\hline \multirow{4}{*}{4} & \multirow{4}{*}{1589} & \multirow{5}{*}{--- } & \multirow{4}{*}{1655} & 274 \\
\hline & & & & 327 \\
\hline & & & & 399 (sh) \\
\hline & & & & 511 \\
\hline \multirow{3}{*}{5} & \multirow{3}{*}{1597} & & \multirow{3}{*}{1652} & 311 \\
\hline & & \multirow[t]{2}{*}{---} & & 391 \\
\hline & & & & 502 \\
\hline
\end{tabular}

*Isocyanurate core carbonyl; ** Chalcone carbonyl

\subsection{Electrochemistry}


The electrochemical behaviors of compounds 1-5 were studied using cyclic voltammetry (CV) in $\mathrm{CH}_{2} \mathrm{Cl}_{2} / 0.1 \mathrm{M} n-\mathrm{Bu}_{4} \mathrm{NPF}_{6}$ (Figure 2), peak potentials are summarized in Table 2. All compounds showed an oxidation signal corresponding to $\mathrm{Fe}^{\mathrm{II}} / \mathrm{Fe}^{\mathrm{III}}$ couple of the ferrocenyl moiety. For compounds 1, 3, 4 and 5 this signal was found to be reversible. Moreover, compound 1 shows a second oxidation signal (See inset in Figure 2) of reversible behavior at $0.774 \mathrm{~V}(\Delta \mathrm{E}=0.074 \mathrm{~V})$, that can be attributed to the differentiation of the ferrocenyl $(\mathrm{Fc})$ moieties present in the molecule. These results are in agreement with those reported by Santi et al. for tris(ferrocenyl) systems, which depend on the kind of the electrolyte support used [19]. For compounds $\mathbf{1}$ and $\mathbf{3}$ where the arm's carbonyl group is absent, a lower current value was observed when compared with that found for compounds 2, 4 and 5, since the solution's working concentrations in all cases were the same (i.e. $10^{-3}$ M) the decrease in the current value can be attributed directly to a decrease in the diffusion coefficient of these molecules, in accordance with the Randles-Sevcik equation[20].

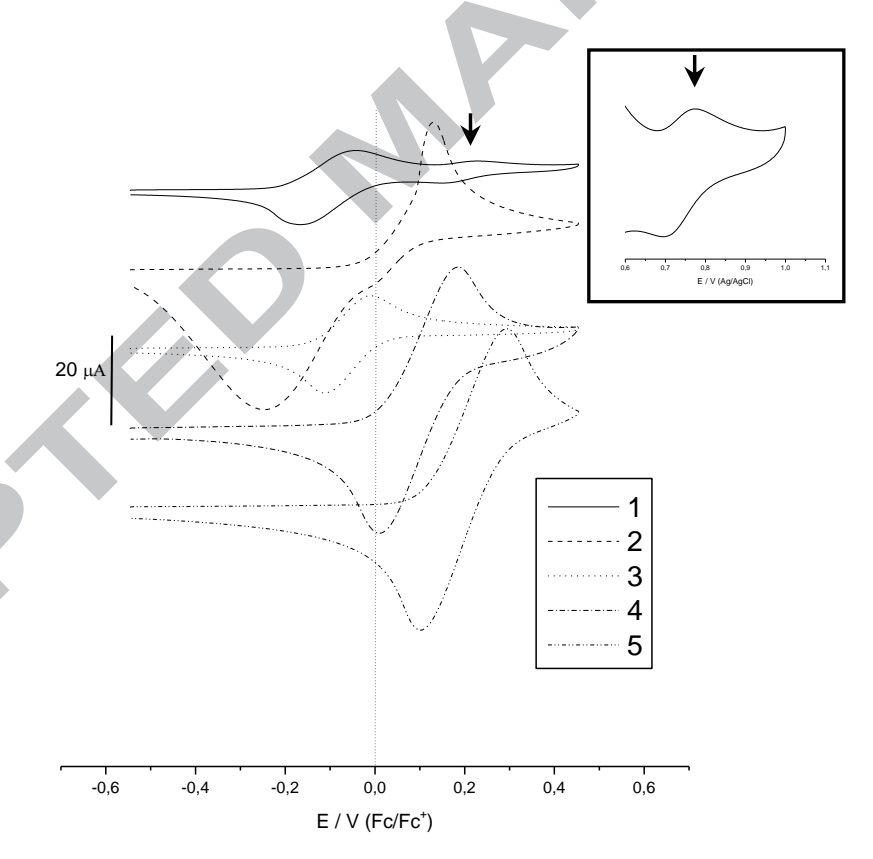

Figure 2. Cyclic Voltammograms of $10^{-3} \mathrm{M}$ solution of all compounds versus $\mathrm{Fc} / \mathrm{Fc}^{+}$ (perpendicular central dot line) in $\mathrm{CH}_{2} \mathrm{Cl}_{2} \cdot 0.1 \mathrm{M}\left[\mathrm{n}-\mathrm{Bu}_{4} \mathrm{~N}\right]\left[\mathrm{PF}_{6}\right]$ as supporting electrolyte with a glassy carbon working electrode, Pt wire auxiliary electrode, scan rate, $0.1 \mathrm{Vs}^{-1}$

In addition, compounds $\mathbf{1}$ and $\mathbf{3}$ showed anodic peak potential values lower than ferrocene compound ( -44 and $-9 \mathrm{mV}$, respectively), this displacement can be explained if the center core behaves as electron donor. This phenomenon could be attributed to their enhanced electron delocalization facilitating the oxidation of the ferocenyl moiety. For 
compounds 2, 4 and 5 bearing a carbonyl group at the 2-propen-1-one moiety, a displacement towards higher potentials values was observed with respect to the ferrocene compound (i.e. 129, 185 and $293 \mathrm{mV}$, respectively). This behavior can be explained by the electron-attracting character of the carbonyl group, thus hindering the oxidation of the ferrocenyl moiety.

When comparing the voltammetric profile of compounds $\mathbf{1}$ and $\mathbf{2}$, both bearing the same isocyanurate core, it was found that they behave very different among them, it seems that the presence of the $-\mathrm{ArC}_{2} \mathrm{H}_{2} \mathrm{CO}$ - fragment, affects the redox mechanism of the $\mathrm{Fc}$ moieties, changing it from reversible to irreversible $(\Delta \mathrm{E}=375 \mathrm{mV})$.

Table 2. Electrochemical data.

\begin{tabular}{|c|c|c|c|c|c|}
\hline Compound & $E_{\mathrm{pa}}(\mathbf{V})^{[\mathbf{a}]}$ & $E_{\mathrm{pc}}(\mathbf{V})^{[\mathbf{b}]}$ & $\Delta E(\mathrm{mV})$ & $i_{\mathrm{pa}}(\mu \mathrm{A})^{[\mathrm{c}]}$ & $i_{\mathrm{pc}}(\mu \mathrm{A})^{[\mathrm{d}]}$ \\
\hline \multirow[t]{2}{*}{1} & 0.503 & 0.380 & 123 & 10.01 & 11.78 \\
\hline & 0.774 & 0.700 & 74 & 0.99 & \\
\hline 2 & 0.676 & 0.301 & 375 & 39.00 & 39.16 \\
\hline 3 & 0.538 & 0.436 & 102 & 13.70 & 15.45 \\
\hline 4 & 0.732 & 0.557 & 175 & 38.41 & 39.97 \\
\hline 5 & 0.840 & 0.648 & 192 & 43.48 & 40.77 \\
\hline $\mathrm{Fc}$ & 0.547 & 0.405 & 142 & 62.16 & 60.41 \\
\hline
\end{tabular}

Anodic peak potential. [b] Cathodic peak potential. [c] Anodic peak current. [d] Cathodic peak current.

\section{Conclusion}

In summary, we have reported here five new compounds, containing ferrocenyl fragments connected by different arm kinds to different central cores. For all of them, except for compound 2, a chemically reversible oxidation wave was observed on the cyclic voltammograms. In contrast, for compound $\mathbf{2}$ a chemically irreversible oxidation wave was observed.

When a carbonyl group is present, as occurs in the chalcone bearing compounds, a displacement towards higher potentials values was observed with respect to the ferrocene standard compound, this being more evident for compound 5. The conjugation with a nearby vinyl linker apparently facilitates the oxidation of ferrocene in compounds $\mathbf{1}$ and $\mathbf{3}$. Finally, the study of the electronic absorption spectra reveals also a bathochromic 
displacement effect produced by the arm linker's nature between the ferrocene and the central core on the lowest energy (MLCT) transition in these compounds.

\section{Acknowledgement}

The authors gratefully acknowledge generous financial support from FONDECYT 11121635 and 11130505 . Also, the grant UNAB DI-5-17/RG, DI-1329-16/R and DI-132216/R.

\section{Experimental Section}

5.1. Materials and physical measurements: Solvents were used as purchased. Reagents were purchased from commercial suppliers and used without further purification. Melting points were determined using a Stuart Scientific SMP3 melting point apparatus. IR spectra were obtained as $\mathrm{KBr}$ disks on a Perkin Elmer Spectrum Two FTIR Spectrometer, in the range of $4000-400 \mathrm{~cm}^{-1} .{ }^{1} \mathrm{H}$ and ${ }^{13} \mathrm{C}$ spectra were acquired at $297 \mathrm{~K}$ on a Bruker Avance 400 NMR spectrometer. Electrochemical measurements were recorded on the Electrochemical Analyzer CH Instruments 620E attached to a desktop computer with the appropriate software for total control of the experiments, data acquisition and treatment; also, a conventional three-electrode cell was used. Glassy carbon electrode (GCE) of $3 \mathrm{~mm}$ diameter (model CHI104, CH Instruments) was used as working electrode. A $0.8 \mathrm{~mm}$ diameter Pt wire and $\mathrm{Ag}|\mathrm{AgCl}| \mathrm{KCl}$ (sat.) electrode (model $\mathrm{CHI111}, \mathrm{CH}$ Instruments) were used as the counter and reference electrodes, respectively. Before each experiment the GCE was pretreated by polishing on 0.3 and $0.05 \mu \mathrm{m}$ alumina. All the experiments were carried out at room temperature. All compounds under study were prepared in dichloromethane solutions $\left(1.0 \times 10^{-3} \mathrm{M}\right)$ and $0.1 \mathrm{M}$ in the supporting electrolyte $n-\mathrm{Bu}_{4} \mathrm{~N}^{+} \mathrm{PF}_{6}$. All chemical shifts are reported in ppm $(\delta)$ relative to tetramethylsilane. Coupling constants $(J)$ are reported in Hertz $(\mathrm{Hz})$ and integrations are reported as number of protons. The following abbreviations are used to describe peak patterns: br, broad; s, singlet; d, doublet; t, triplet; m, multiplet; pst, pseudo triplet, dd, double doublet; brs, broad singlet. Elemental analyses were conducted on a Thermo-FINNIGAN Flash EA 1112 CHNS/O analyzer. The geometry optimizations of compound $\mathbf{1}$ and $\mathbf{2}$ were performed at the B3LYP[21,22]/SDD[23] level of calculation. The obtained structures were corroborated as minimum through vibrational analysis at B3LYP/6-31G*[24]and the $\mathrm{SDD}[25]$ basis set for iron. Excited state 
calculations were performed within the time-dependent DFT methodology at the same calculation level. Solvent effect for simulating dichloromethane has been incorporated through the polarizable continuum model (PCM)[26]. All of these calculations were made using Gaussian09 package of programs (G09)[27]. Absorption spectra were obtained from using the GaussSum 3.0[28] suite of processing tools. A full width at half-maximum (fwhm) of the Gaussian curves corresponding to $3000 \mathrm{~cm}-1$ was employed to convolute the spectra. The representation of molecular orbitals was made using the G09 cubegen tool and has been visualized using GV09 package.

5.2. General procedure for compounds 1 and 3: In an Schlenk tube under argon one of the following central cores $\mathbf{C 1}$, or $\mathbf{C 2}$ was mixed with $5 \%$ palladium(II) acetate, $\mathrm{Pd}(\mathrm{OAc})_{2}$, 10\% Tris (o-tolyl)phosphine, $\mathrm{P}(\mathrm{o} \text {-tol })_{3}$, and vinyl ferrocene, $\mathbf{1 - F c}$, in triethylamine/THF, 15 $\mathrm{mL} / 15 \mathrm{~mL}$. The resulting mixture was stirred and refluxed overnight. After removing the solvent under reduced pressure, the oil obtained was washed with distillated water and extracted in $\mathrm{CH}_{2} \mathrm{Cl}_{2}$ three times and dried over $\mathrm{MgSO}_{4}$. The extract was concentrated to dryness and purified by column chromatography (silica gel 60 ) using hexane/ $\mathrm{CH}_{2} \mathrm{Cl}_{2} 2: 1$ $(\mathrm{V} / \mathrm{V})$ mixtures as eluent. The corresponding compounds were isolated after removing the solvent in a rotary evaporator.

Compound 1. 1-Fc (187 mg, $8.84 \mathrm{mmol}), \mathbf{C 1}(150 \mathrm{mg}, 0.253 \mathrm{mmol}), \mathrm{Pd}(\mathrm{OAc})_{2}(2.8 \mathrm{mg}$, $0.0126 \mathrm{mmol}), \mathrm{P}(\mathrm{o}-\mathrm{tol}) 3(7.7 \mathrm{mg}, 0.0253 \mathrm{mmol})$, triethylamine $/ \mathrm{THF}, 15 \mathrm{~mL} / 15 \mathrm{~mL}$. Yield 49.5\%. IR wavenumber (KBr): $\tilde{V}=1713 \mathrm{~cm}^{-1}(-\mathrm{C}=\mathrm{O}), 1590 \mathrm{~cm}^{-1}(-\mathrm{C}=\mathrm{C}-) .{ }^{1} \mathrm{H} \mathrm{NMR}\left(\mathrm{CDCl}_{3}\right.$, $400 \mathrm{MHz}): \delta=4.10\left(15 \mathrm{H}, \mathrm{pst}, \mathrm{C}_{5} \mathrm{H}_{5}\right), 4.27\left(6 \mathrm{H}, \mathrm{pst}_{-} \mathrm{C}_{5} \mathrm{H}_{4}\right), 4.44\left(6 \mathrm{H}, \mathrm{s},-\mathrm{C}_{5} \mathrm{H}_{4}\right), 6.68(3 \mathrm{H}$, d, $J=16.0 \mathrm{~Hz},=\mathrm{CH}), 6.89(3 \mathrm{H}, \mathrm{d}, J=16.0 \mathrm{~Hz},=\mathrm{CH}), 7.31\left(6 H, \mathrm{~d}, J=8.2 \mathrm{~Hz}, \mathrm{H}_{\text {arom }}\right), 7.50$ $\left(6 \mathrm{H}, \mathrm{d}, \mathrm{J}=8.4 \mathrm{~Hz}, \mathrm{H}_{\text {arom }}\right) .{ }^{13} \mathrm{C}$ NMR $\left(100.6 \mathrm{MHz}, \mathrm{CDCl}_{3}\right): \delta=67.05,69.25,69.66,82.76$, $124.74,126.48,128.53,128.60,128.91,131.70,139.04$. Analysis calculated for $\mathrm{C}_{57} \mathrm{H}_{45} \mathrm{O}_{3} \mathrm{Fe}_{3} \mathrm{~N}_{3}: \mathrm{C}, 69.3 ; \mathrm{H}, 4.59 ; \mathrm{N}, 4.26$. Found: $\mathrm{C}, 68.61 ; \mathrm{H}, 4.12 ; \mathrm{N}, 4.32 . \mathrm{MP}: 199{ }^{\circ} \mathrm{C}-$ $200^{\circ} \mathrm{C}$.

Compound 3. 1-Fc (137 mg, $0.648 \mathrm{mmol}), \mathbf{C 2}(100 \mathrm{mg}, 0.162 \mathrm{mmol}), \mathrm{Pd}(\mathrm{OAc})_{2}(1.8 \mathrm{mg}$, $0.0081 \mathrm{mmol}), \mathrm{P}(\mathrm{o}-\mathrm{tol})_{3}(5.0 \mathrm{mg}, 0.0162 \mathrm{mmol})$, triethylamine $/ \mathrm{THF}, 15 \mathrm{~mL} / 15 \mathrm{~mL}$. Yield 51.2\%. IR wavenumber $(\mathrm{KBr}): \tilde{v}=2206 \mathrm{~cm}^{-1} \quad(-\mathrm{C} \equiv \mathrm{C}-), 1578 \mathrm{~cm}^{-1} \quad(-\mathrm{C}=\mathrm{C}-) .{ }^{1} \mathrm{H}$ NMR $\left(\mathrm{CDCl}_{3}, 400 \mathrm{MHz}\right): \delta=4.16\left(15 \mathrm{H}, \mathrm{s}, \mathrm{C}_{5} \mathrm{H}_{5}\right), 4.32\left(6 \mathrm{H}, \mathrm{spt}-\mathrm{C}_{5} \mathrm{H}_{4}\right), 4.48\left(6 \mathrm{H}, \mathrm{spt},-\mathrm{C}_{5} \mathrm{H}_{4}\right)$, $6.69(3 H, \mathrm{~d}, J=16.1 \mathrm{~Hz},=\mathrm{CH}), 6.94(3 \mathrm{H}, \mathrm{d}, J=16.1 \mathrm{~Hz},=\mathrm{CH}), 7.42(6 H, \mathrm{~d}, J=8.7 \mathrm{~Hz}$, $\left.\mathrm{H}_{\text {arom }}\right), 7.49\left(6 \mathrm{H}, \mathrm{d}, J=6.0 \mathrm{~Hz}, \mathrm{H}_{\text {arom }}\right), 7.66\left(3 \mathrm{H}, \mathrm{t}, \mathrm{C}_{6} \mathrm{H}_{3}\right) .{ }^{13} \mathrm{C} \mathrm{NMR}\left(100.6 \mathrm{MHz}, \mathrm{CDCl}_{3}\right): \delta$ $=67.05,69.29,69.32,69.68,82.92,82.94,88.33,91.13,100.00,120.70,122.91,125.20$, 
125.71, 128.58, 131.73, 132.05, 133.11, 133.80, 138.30. Analysis calculated for $\mathrm{C}_{66} \mathrm{H}_{48} \mathrm{Fe}_{3}$ : C, 78.59; H, 4.80; Found: C, 78.30; H, 4.67. MP: $206^{\circ} \mathrm{C}-211^{\circ} \mathrm{C}$.

5.3. General procedure for compounds 2,4 and 5: In an Schlenk tube under argon one of the following central cores $\mathbf{C 1}$ or $\mathbf{C 4}$ was mixed with $5 \%$ bis(triphenylphosphine)palladium(II) dichloride, $\mathrm{Pd}(\mathrm{Cl})_{2}\left(\mathrm{PPh}_{3}\right)_{2}, \quad 10 \%$ copper(I) iodide, $\mathrm{CuI}$, and, 2-Fc, 3-Fc or 4-Fc, in $15 \mathrm{~mL}$ of triethylamine. The resulting mixture was stirred at room temperature overnight. After removing the solvent under reduced pressure, the crude was redissolved in $\mathrm{CH}_{2} \mathrm{Cl}_{2}$ and filtrated through Celite ${ }^{\circledR 545}$. The extract was concentrated to dryness and purified by column chromatography (silica gel 60) in hexane/ $\mathrm{CH}_{2} \mathrm{Cl}_{2}$ 2:1 (V/V). The corresponding compound was isolated after removing the solvent in a rotary evaporator.

Compound 2: 2-Fc (343 mg, $1.01 \mathrm{mmol}), \mathbf{C 1}(200 \mathrm{mg}, 0.337 \mathrm{mmol}), \mathrm{Pd}(\mathrm{Cl})_{2}\left(\mathrm{PPh}_{3}\right)_{2}(11.8$ $\mathrm{mg}, 0.0169 \mathrm{mmol})$, CuI (6.4 mg, $0.0337 \mathrm{mmol})$, triethylamine $15 \mathrm{~mL}$. Yield 53.0\%. IR wavenumber $(\mathrm{KBr}): \tilde{v}=1719 \mathrm{~cm}^{-1}(-\mathrm{C}=\mathrm{O}$, core $), 1588 \mathrm{~cm}^{-1}(-\mathrm{C}=\mathrm{C}-)$ and $1655 \mathrm{~cm}^{-1}(-\mathrm{C}=\mathrm{O}$, chalcone). ${ }^{1} \mathrm{H} \mathrm{NMR}\left(\mathrm{CDCl}_{3}, 400 \mathrm{MHz}\right): \delta=4.19\left(15 H, \mathrm{~s}, \mathrm{C}_{5} \mathrm{H}_{5}\right), 4.52\left(6 H, p s t,-\mathrm{C}_{5} \mathrm{H}_{4}\right)$, $4.62\left(6 \mathrm{H}, \mathrm{pst},-\mathrm{C}_{5} \mathrm{H}_{4}\right), 7.10(3 \mathrm{H}, \mathrm{d}, J=15.3 \mathrm{~Hz},=\mathrm{CH}), 7.59-7.70\left(17 \mathrm{H}, \mathrm{m}, \mathrm{H}_{\text {arom }}\right), 7.79$ $(3 \mathrm{H}, \mathrm{d}, J=15.3 \mathrm{~Hz},=\mathrm{CH}), 7.97\left(7 \mathrm{H}, \mathrm{d}, J=8.4 \mathrm{~Hz}, \mathrm{H}_{\text {arom }}\right) .{ }^{13} \mathrm{C} \mathrm{NMR}\left(100.6 \mathrm{MHz}, \mathrm{CDCl}_{3}\right)$ : $\delta=69.16,69.89,71.66,76.37,79.01,82.17,118.56,123.70,125.51,128.36,130.03$, $131.85,132.28,132.68,132.72,138.88,147.74,148.01,188.61$. Analysis calculated for $\mathrm{C}_{84} \mathrm{H}_{57} \mathrm{O}_{6} \mathrm{Fe}_{3} \mathrm{~N}_{3}: \mathrm{C}, 73.54 ; \mathrm{H}, 4.19 ; \mathrm{N}, 3.06$. Found: $\mathrm{C}, 74.35 ; \mathrm{H}, 4.21 ; \mathrm{MP}: 210^{\circ} \mathrm{C}-211{ }^{\circ} \mathrm{C}$

Compound 4. 3-Fc (565mg, $1.43 \mathrm{mmol}), \mathbf{C 4}(71.4 \mathrm{mg}, 0.476 \mathrm{mmol}), \mathrm{Pd}(\mathrm{Cl})_{2}\left(\mathrm{PPh}_{3}\right)_{2}(16.7$ $\mathrm{mg}, 0.0238 \mathrm{mmol})$, CuI $(9.1 \mathrm{mg}, 0.0476 \mathrm{mmol})$, triethylamine $15 \mathrm{~mL}$. Yield $40.6 \%$. IR wavenumber $(\mathrm{KBr}): \tilde{v}=1655(-\mathrm{C}=\mathrm{O}-), 1589(-\mathrm{C}=\mathrm{C}-) .{ }^{1} \mathrm{H}$ NMR $\left(\mathrm{CDCl}_{3}, 400 \mathrm{MHz}\right): \delta=$ $4.18\left(15 H, \mathrm{~s}, \mathrm{C}_{5} \mathrm{H}_{5}\right), 4.50\left(6 \mathrm{H}, \mathrm{pst},-\mathrm{C}_{5} \mathrm{H}_{4}\right), 4.59\left(6 \mathrm{H}, \mathrm{pst},-\mathrm{C}_{5} \mathrm{H}_{4}\right), 7.06(3 \mathrm{H}, \mathrm{d}, J=15.3 \mathrm{~Hz}$, $=\mathrm{CH}), 7.62\left(6 \mathrm{H}, \mathrm{d}, J=8.4 \mathrm{~Hz}, \mathrm{C}_{6} H_{3}\right), 7.76(3 \mathrm{H}, \mathrm{d}, J=15.3 \mathrm{~Hz},=\mathrm{CH}), 7.84(6 \mathrm{H}, \mathrm{d}, J=8.4$ $\left.\mathrm{Hz}, \mathrm{C}_{6} \mathrm{H}_{3}\right) .{ }^{13} \mathrm{C} \mathrm{NMR}\left(\mathrm{CDCl}_{3}, 400 \mathrm{MHz}\right): \delta=69.11,69.86,71.60,78.98,118.46,127.35$, $129.89,131.81,137.38,147.60,188.62$. Analysis calculated for $\mathrm{C}_{69} \mathrm{H}_{48} \mathrm{Fe}_{3} \mathrm{O}_{3}: \mathrm{C}, 75.85 ; \mathrm{H}$, 4.43; Found: C, 75.20; H, 4.67. MP: $203^{\circ} \mathrm{C}-200^{\circ} \mathrm{C}$ 
Compound 5. 4-Fc (700 mg, $1.77 \mathrm{mmol}), \mathbf{C 4}(88.5 \mathrm{mg}, 0.590 \mathrm{mmol}), \mathrm{Pd}(\mathrm{Cl})_{2}\left(\mathrm{PPh}_{3}\right)_{2}(21$ mg, $0.0295 \mathrm{mmol})$, CuI (11 mg, $0.0590 \mathrm{mmol})$, triethylamine $15 \mathrm{~mL}$. Yield 56.5\%. IR wavenumber $(\mathrm{KBr}): \tilde{v}=1652(-\mathrm{C}=\mathrm{O}-), 1597(-\mathrm{C}=\mathrm{C}-) .{ }^{1} \mathrm{H} \mathrm{NMR}\left(\mathrm{CDCl}_{3}, 400 \mathrm{MHz}\right): \delta=$ $4.22\left(15 H, \mathrm{~s}, \mathrm{C}_{5} \mathrm{H}_{5}\right), 4.61\left(6 H, p s t,-\mathrm{C}_{5} \mathrm{H}_{4}\right), 4.91\left(6 H, p s t,-\mathrm{C}_{5} \mathrm{H}_{4}\right), 7.10(3 H, \mathrm{~d}, J=15.7 \mathrm{~Hz}$, $=\mathrm{CH}), 7.53\left(15 \mathrm{H}, \mathrm{dd}, \mathrm{C}_{6} \mathrm{H}_{3}\right.$ and $\left.-\mathrm{C}_{6} H_{4^{-}}\right), 7.72(3 \mathrm{H}, \mathrm{d}, J=15.7 \mathrm{~Hz},=\mathrm{CH}) .{ }^{13} \mathrm{C} \mathrm{NMR}$ $\left(\mathrm{CDCl}_{3}, 100.6 \mathrm{MHz}, \mathrm{CDCl}_{3}\right): \delta=69.76,70.14,72.92,80.48,123.51,124.25,129.63$, 132.18, 133.68, 134.15, 139.47, 192.68. Analysis calculated for $\mathrm{C}_{69} \mathrm{H}_{48} \mathrm{Fe}_{3} \mathrm{O}_{3}: \mathrm{C}, 75.85 ; \mathrm{H}$, 4.43; Found: C, 75.15; H, 4.67. MP: $203^{\circ} \mathrm{C}-205^{\circ} \mathrm{C}$.

\section{References}

[1] D.I. Bezuidenhout, B. Van Der Westhuizen, I. Strydom, P.J. Swarts, J.C. Swarts, I. Fernández, Synthesis and electrochemical investigation of chromium(0) ferrocenylsubstituted carbene complexes, Inorganica Chim. Acta. 423 (2014) 184-192.

[2] W.C. Du Plessis, W.L. Davis, S.J. Cronje, J.C. Swarts, Structural, thermodynamic and kinetic consequences of a spectroscopic study of the equilibrium between isomeric forms of ferrocene-containing $\beta$-diketones, Inorganica Chim. Acta. 314 (2001) 97104.

[3] A. Hildebrandt, T. Rüffer, E. Erasmus, J.C. Swarts, H. Lang, A star-shaped supercrowded 2,3,4,5-tetraferrocenylthiophene: Synthesis, solid-state structure, and electrochemistry, Organometallics. 29 (2010) 4900-4905.

[4] U. Pfaff, A. Hildebrandt, D. Schaarschmidt, T. Hahn, S. Liebing, J. Kortus, H. Lang, Di- and triferrocenyl (hetero)aromatics: Synthesis, characterization, (spectro)electrochemistry, and calculations, Organometallics. 31 (2012) 6761-6771.

[5] A.R. Pike, L.C. Ryder, B.R. Horrocks, W. Clegg, B.A. Connolly, A. Houlton, Ferrocenyl-modified DNA: Synthesis, characterization and integration with semiconductor electrodes, Chem. A Eur. J. 11 (2005) 344-353.

[6] F. Spänig, C. Kovacs, F. Hauke, K. Ohkubo, S. Fukuzumi, D.M. Guldi, A. Hirsch, Tuning charge transfer energetics in reaction center mimics via Th-functionalization of fullerenes, J. Am. Chem. Soc. 131 (2009) 8180-8195.

[7] S. Brooker, Complexes of thiophenolate-containing Schiff-base macrocycles and their amine analogues, Coord. Chem. Rev. 222 (2001) 33-56.

[8] F. Ossola, P. Tomasin, F. Benetollo, E. Foresti, P.A. Vigato, Synthesis, structure and properties of new ferrocene-containing compounds, Inorganica Chim. Acta. 353 (2003) 292-300. 
[9] A.E. Martell, J. Perutka, D. Kong, Dinuclear metal complexes and ligands: Stabilities and catalytic effects, Coord. Chem. Rev. 216 (2001) 55-63.

[10] V. Amendola, L. Fabbrizzi, C. Mangano, P. Pallavicini, A. Poggi, A. Taglietti, Anion recognition by dimetallic cryptates, Coord. Chem. Rev. 219-221 (2001) 821-837.

[11] A. Trujillo, F. Ocayo, V. Artigas, J.C. Santos, P. Jara-Ulloa, S. Kahlal, J.-Y. Saillard, M. Fuentealba, C.A. Escobar, New ferrocenyl-chalcones and bichalcones: Synthesis and characterization, Tetrahedron Lett. 58 (2017) 437-441.

[12] J. Palomero, J.A. Mata, F. González, E. Peris, Facile synthesis of first generation ferrocene dendrimers by a convergent approach using ditopic conjugated dendrons, New J. Chem. 26 (2002) 291-297.

[13] G. Argouarch, R. Veillard, T. Roisnel, A. Amar, H. Meghezzi, A. Boucekkine, V. Hugues, O. Mongin, M. Blanchard-Desce, F. Paul, Triaryl-1,3,5-triazinane-2,4,6triones (isocyanurates) peripherally functionalized by donor groups: synthesis and study of their linear and nonlinear optical properties., Chem. Eur. J. 18 (2012) 11811-11827.

[14] F. Wang, B.R. Kaafarani, D.C. Neckers, Synthesis of silicon-containing unsaturated polymers by hydrosilylation reaction. Photophysical studies, Macromolecules. 36 (2003) 8225-8230.

[15] C.A. Escobar, D. Gutierrez, M. Verdugo, F. Madrid, J.C. Santos, P. Jara-Ulloa, A. Trujillo, Synthesis and characterization of new mono and bi-nuclear ferrocene derivatives connected via a cross-conjugated prop-2-en-1-one bridge, J. Organomet. Chem. 830 (2017) 1-10.

[16] X. Wu, P. Wilairat, M.L. Go, Antimalarial activity of ferrocenyl chalcones, Bioorg. Med. Chem. Lett. 12 (2002) 2299-2302.

[17] J. Maynadié, B. Delavaux-Nicot, D. Lavabre, S. Fery-Forgues, Monosubstituted ferrocenyl chalcones: Effect of structural changes upon the ability to detect calcium by absorption spectroscopy, J. Organomet. Chem. 691 (2006) 1101-1109.

[18] E. Erasmus, Ferrocene- and ruthenocene-containing chalcones: A spectroscopic and electrochemical study, Inorg. Chim. Acta. 378 (2011) 95-101.

[19] S. Santi, A. Bisello, R. Cardena, A. Donoli, Key multi(ferrocenyl) complexes in the interplay between electronic coupling and electrostatic interaction, Dalt. Trans. 44 (2015) 5234-5257.

[20] P.T. Kissinger, W.R. Heineman, Cyclic voltammetry, J. Chem. Educ. 60 (1983) 702.

[21] A.D. Becke, Densityfunctional thermochemistry . III . The role of exact exchange, J. 
Chem. Phys. 98 (1993) 5648-5652.

[22] C. Lee, W. Yang, R.G. Parr, Development of the Colle-Salvetti correlation-energy formula into a functional of the electron density, Phys. Rev. B. 37 (1988) 785-789.

[23] H.F. Schaefer, Methods of Electronic Structure Theory, Vol. 3, Springer US, New York, 1977.

[24] R. Ditchfield, W.J. Hehre, J.A. Pople, Self-Consistent Molecular-Orbital Methods. IX. An Extended Gaussian-Type Basis for Molecular-Orbital Studies of Organic Molecules, J. Chem. Phys. 54 (1971) 724-728.

[25] M. Dolg, U. Wedig, H. Stoll, and H. Preuss, "Energy-adjusted ab initio pseudopotentials for the first row transition elements," J. Chem. Phys. 86 (1987) 866-72.

[26] G. Scalmani, M.J. Frisch, Continuous surface charge polarizable continuum models of solvation . I . General formalism, J. Chem. Phys. 132 (2015) 114110.

[27] M.J. Frisch, al. et., Revision C, (2009) Gaussian, Inc., Wallingford CT, 2009.

[28] N.M. O’Boyle, A.L. Tenderholt, K.M. Langner, cclib: A Library for PackageIndependent Computational Chemistry Algorithms, J. Comput. Chem. 29 (2008) $839-845$. 

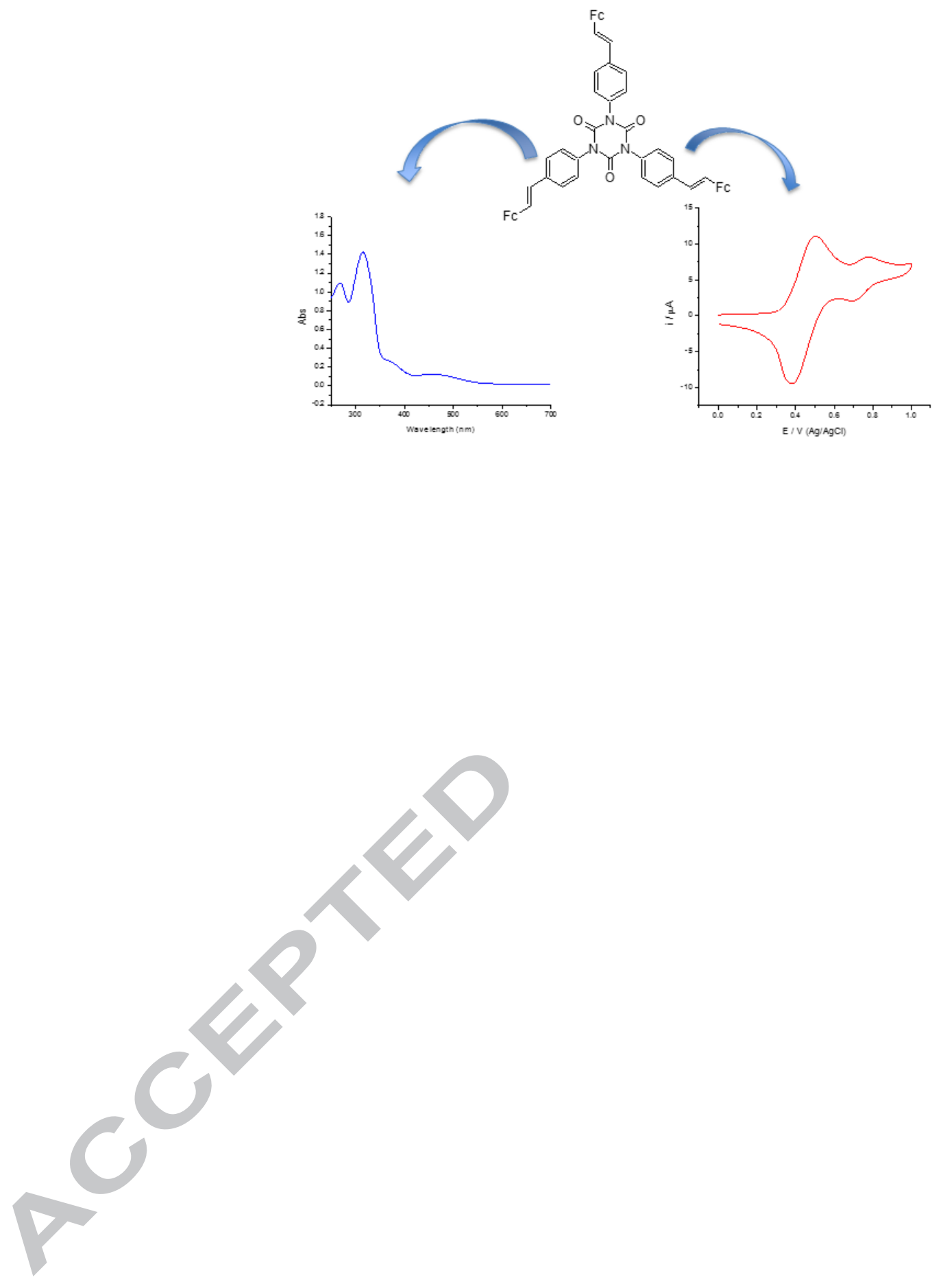


\section{Highlights:}

- New star like ferrocenyl compounds containing two different central cores have been synthesized

- The oxidation of ferrocenyl is facilitated by conjugation of vinyl linker through central core

- Bathochromic shift in absorption spectra was observed based on the nature of linker 